\title{
Apology Strategies of Indonesian Hotel Managements in Handling Complaints Written in Travel Site
}

\author{
Agita Risma Nurhikmawati, Universitas PGRI Madiun \\ Dhika Puspitasari, Universitas PGRI Madiun
}

\begin{abstract}
The research which is entitled "Apology Strategies of Indonesian Hotel Managements in Handling Complaints Written in a Travel Site" tries to describe the apology strategies used by hotel managements in responding the complaints from their customer regarding the hotel services. The way they react to the complaints assuredly influences the personal judgments of their potential customers. Furthermore the perception affects the profit of the company. The objectives of this study are: (1) to portray the strategies of hotel management in apologizing found in the review column of a travel site, and (2) to explain the differences and similarities of the strategies applied in each classification of hotel. This research uses descriptive qualitative method that is conducted solely based on fact or phenomenon that exists. The data are obtained from international travel site, namely Trip Advisor and done by using recording technique. Then, the data are classified based on hotels' stars and managements. The classification of star is divided into four, ranging from two to five stars hotel which are located in all over Indonesia, whereas the classification of management is divided into two namely national and international based hotels. Ten negative reviews which responded by the hotel management with a speech of apology are taken at every level of hotel. The obtained data is then analyzed using Trosborg's theory of apology strategies.
\end{abstract}

Keywords: apology strategies; hotel management; travel site.

\section{Introduction}

Travel site is one of media that provides convenience for its customers spread all over the world by offering various contents such as hotels, airlines, restaurants, trains, and others. One of the contents provided on the site is review which also plays an important role to highlight the company's strength and quality so that customers are interested. It is important for the customers to ascertain whether what is described by the company is really offered and available to be ordered (Rianthong, et al., 2016). Review means telling the experience of someone who has used the services of a company by describing the advantages or the shortcomings. In addition, the site also makes certain indicators that can be filled by the customers to rank their satisfaction levels. The customers' given reviews are certainly not only positive reviews, but also negative critiques which get responses from the company. That second type of review can lead to a risk of dropping company's reputation in online communities. Therefore, the company must respond wisely (Litvin, Goldsmith, \& Pan, 2008). Reviews from the customers as well as responses from the companies have been pre-selected by travel sites to bypass their regulatory system, but the site will not replace or modify the language of the reviews or the responses. The interesting thing to look at is the use of apology strategies by company managements against customers' negative reviews which have multi-cultural background.

Apology is part of expressive speech which aimed to provide support to actual or potential partners who did the offense (Olshtain \& Cohen, 1983). In line with that, Revita (2005) stated that apology is an utterance which contains action so that the opposite speakers follow and do as it said. Based on this, the speaker must choose a good strategy to realize the goal of apology.

Trosborg (1987) stated that there are two responses that can be taken by the complain receiver in reaching the complainer, (1) does not take on responsibilities and (2) takes on responsibilities (using apology strategy). When the complain receiver does not take on responsibilities, there are two actions to be taken, first is to not accept that complaint and second is to accept the occurred complaint. The strategies used to not accept the complaint can be in the form of explicit denial and implicit denial. While the strategies applied to accept the complaint can be in the form of justification and blame. Blame is subdivided into two, those are: blames the $\mathrm{X}$ and blames the complainer or 'attack'. 
Apology strategy is used when complain receiver takes on responsibilities. Trosborg (1987) stated that there are seven apology strategies.

1. Minimizing the degree of offence, which consists of: (a) minimizing, (b) querying preconditions, and (c) blaming someone else.

2. Acknowledgement of responsibility, which is divided into: (a) implicit acknowledgment, $\{b\}$ explicit acknowledgment, (c) expression of lack of intent, (d) expression of self-deficiency, (e) expression of embarrassment, and (f) explicit acceptance of the blame.

3. Explanation or account, which consists of (a) implicit and (b) explicit explanation.

4. Expression of apology, which includes (a) expression of regret, (b) offer of apology, and (c) request for forgiveness.

5. Offer of repair, which consists of (a) repair and (b) compensation.

6. Promise of forbearance.

7. Expressing concern for hearer.

Based on the previous explanation, this research has a purpose to examine the apology strategies used by the hotel managements to handle complaints from the customers on the travel site. The hotel management in this study is divided into two, namely international chain/ international based hotels (ICH) and non-international chain/ national based hotels(NICH). In addition, this study also examines the differences and similarities of apology strategies used by both of managements.

\section{Research method}

This study uses descriptive qualitative method. This descriptive research is conducted solely based on the fact that exists or the phenomenon that is empirically alive on the speakers so that it generates portions of language such as description or in the form of what it is (Sudaryanto, 1986). The source of data in this study is the answer which was written by hotel management in handling negative reviews provided by consumers found in an international travel site, Trip Advisor. It is selected since this site is so popular, has many customers around the world, and has 'reviews' feature that can be responded by the concerned company.

The data were collected according to the classification of ICH and NICH. Each classification is subdivided based on the hotel quality level of two, three, four, and five-star hotel. At each level of hotel, ten negative reviews responded by the hotel management using apology strategy were taken, thus the data are 40 negative reviews in total for ICH and 40 negative reviews for $\mathrm{NICH}$. The data were compiled from January 2017 to February 2018 and the choice of the hotel was based on the presence or absence of managements' response to negative reviews. The ICH that became the data in this study were Fave, Swiss Bellinn, Alana, and Sheraton, while the NICH were Wisma Aji Yogyakarta, Omah Sabah Yogyakarta, Red Planet Hotel Surabaya, La Walon Hotel, Hotel 1001 Malam Yogyakarta, Duta Guest House Yogyakarta, Elephant Biru Bungalow Bali, Prawirotaman Gallery Yogyakarta, Nyuh Bali Vila, Tugu Bali Hotel, and Hotel Tentrem Yogyakarta.

The step of data analysis was first classifying them based on the Trosborg theory for each level and type. Next, the researchers found out the pattern of the apology strategies structure when the employed ones were more than one, and put the distributions of the strategies in table (in percent). After that, ICH and NICH were compared in each level of two, three, four, and five-star hotels and discussed the result. Finally, a conclusion was made to recap the whole idea.

\section{Result and Discussion}

Table 1: Distribution of Strategies by ICH and NICH

\begin{tabular}{|l|c|c|c|c|c|c|c|c|}
\hline \multirow{2}{*}{ Strategies } & \multicolumn{4}{|c|}{ ICH } & \multicolumn{4}{|c|}{ NICH } \\
\cline { 2 - 8 } & $\begin{array}{l}\text { Two- } \\
\text { star }\end{array}$ & $\begin{array}{l}\text { Three- } \\
\text { star }\end{array}$ & $\begin{array}{l}\text { Four- } \\
\text { star }\end{array}$ & $\begin{array}{l}\text { Five- } \\
\text { star }\end{array}$ & $\begin{array}{l}\text { Two- } \\
\text { star }\end{array}$ & $\begin{array}{l}\text { Three- } \\
\text { star }\end{array}$ & $\begin{array}{l}\text { Four- } \\
\text { star }\end{array}$ & $\begin{array}{l}\text { Five- } \\
\text { star }\end{array}$ \\
\hline $\begin{array}{l}\text { Does not take on } \\
\text { responsibility }\end{array}$ & $9.1 \%$ & - & $23.5 \%$ & - & - & $19 \%$ & $13.6 \%$ & - \\
\hline
\end{tabular}


Table 1, cont.

\begin{tabular}{|l|r|r|r|r|r|r|r|r|}
\hline Take on responsibility & & & & & & & - \\
\hline $\begin{array}{l}\text { 1.Minimizing the degree of } \\
\text { offence }\end{array}$ & - & $3.6 \%$ & - & - & - & - & - & - \\
\hline $\begin{array}{l}\text { 2.Acknowledgement of } \\
\text { responsibility }\end{array}$ & $4.5 \%$ & - & - & $3.3 \%$ & - & - & - & - \\
\hline 3.Explanation & $22.7 \%$ & $17.9 \%$ & - & $6.7 \%$ & $17.4 \%$ & $9.5 \%$ & $9 \%$ & $24 \%$ \\
\hline 4.Expression of apology & $27.2 \%$ & $35.7 \%$ & $23.5 \%$ & $30 \%$ & $47.8 \%$ & $43 \%$ & $41 \%$ & $48 \%$ \\
\hline 5.Offer of repair & - & - & - & - & - & $19 \%$ & $13.6 \%$ & $4 \%$ \\
\hline $\begin{array}{l}\text { 6.Promise of forbearance } \\
\text { 7.Expressing concern for } \\
\text { hearer }\end{array}$ & $4.5 \%$ & $42.9 \%$ & $52.9 \%$ & $43.3 \%$ & $34.8 \%$ & $9.5 \%$ & $18.2 \%$ & $24 \%$ \\
\hline $\begin{array}{l}\text { Total number of } \\
\text { responses }\end{array}$ & 22 & 28 & 17 & 30 & 23 & 21 & 22 & 25 \\
\hline
\end{tabular}

\subsection{Two-star hotel}

In general, two-star hotels in either ICH or NICH accept the fact that there have been complaints from consumers. The difference is that NICH took responsibility for all complaints, while $9.1 \%$ of ICH did not take on responsibility. The most widely used apology strategy for NICH is expression of apology (47.8\%), whereas in $\mathrm{ICH}$ is a promise of forbearance (31.8\%). In addition to the expression of apology, NICH also uses two other strategies namely: explanation (17.4\%) and promise of forbearance (34.8\%). Therefore, the total apology strategies used by NICH are three strategies. This is different from ICH because the apology strategies used are more varied up to five strategies. In addition to the promise of forbearance as the most widely used strategy, there are four other strategies: acknowledgement of responsibility (4.5\%), expressing concern for hearer $(4.5 \%)$, explanation $(22.7 \%)$, and expression of apology (27.2\%). ICH and NICH did not utilize strategy 1 and 5 in response to consumer complaints.

In ICH, there are several cases in not taking responsibility on consumer complaints. This is indicated by the use of explicit denial by management. Explicit denial is shown by negation tidak or not. This word serves to express denial and rejection of consumer complaints. In addition to the use of the word negation, ICH also uses the noun phrase of klarifikasi ulang or re-clarification as a form of rejection. This phrase sends signal indicating that the management is not only providing one answer to consumers, so it can be assumed that explicitly the hotel management is not responsible for complaints that occur.

The similarities of apology strategies between ICH and NICH are the use of explanation, expression of apology, and promise of forbearance. ICH and NICH do not employ special vocabulary in implementing strategy of explanation. In general, both ICH and NICH directly provides answers or explanations related to the problem. On the other hand, expression of apology as the strategy used by $\mathrm{NICH}$ is more varied. NICH applies three strategies that include: expression of regret, offer of apology, and request for forgiveness, whereas ICH only uses one strategy, which is request for forgiveness. This is due to the differences of the language of the data; almost all data on the NICH are in English while in $\mathrm{ICH}$, the data are expressed in Indonesian. English lets NICH to use specific vocabulary such as adjective sorry for expression of regret, and verb apologize and also noun inconvenience for the offer of apology. While the request for forgiveness, both ICH and NICH employ similar verb phrases memohon maaf / meminta maaf or to ask pardon since both data are in Indonesian language. The diction in promise for forbearance which delivered by ICH and $\mathrm{NICH}$ are positive vocabularies that illustrate their promise or commitment. ICH presents more varied vocabularies such as verbs memperbaiki or to fix and mengevaluasi or to evaluate, nouns perbaikan or the repair, masukan or the advice, and evaluasi or the evaluation. However, NICH uses verb advise and noun improvement.

Other apology strategies that only appeared on ICH are acknowledgment of responsibility and expressing concern for hearer. To demonstrate implicit acknowledgment of responsibility, ICH writes 
phrase tidak seharusnya terjadi or should not occur which indicates that the management implicitly admitted the mistakes they have made. As for expressing concern for hearer, ICH shows sympathy to the consumers by using negative verb phrase tidak memenuhi harapan Anda or does not meet your expectations.

\subsection{Three-star hotel}

Generally, ICH and NICH in this classification accept the fact that there have been complaints from consumers. The difference is that ICH takes responsibility for all consumer complaints, while 19\% $\mathrm{NICH}$ does not take on responsibility. NICH produces several cases not take on responsibility by attacking the complainer (blames the complainer 'attack'). Negative and coarse expressions are the hallmark of this strategy to abuse the consumer. As the example, NICH writes expressions guest is always right and not a problem if you're not like to come back in response to consumer complaints. Furthermore, the most widely used apology strategy by ICH is promise of forbearance (42.9\%), while NICH presents 43\% expression of apology. In addition to the promise of forbearance, ICH also delivers three other strategies: minimizing the degree of offense (3.6\%), explanation (17.9\%), and expression of apology (35.7\%). While NICH employed explanation (9.5\%), offer of repair (19\%), and promise of forbearance $(9.5 \%)$ as well. ICH and NICH do not apply strategy 2 and 7 in response to consumer complaints.

The similarity of the apology strategy between ICH and NICH is the use of explanation, expression of apology, and promise of forbearance. Implicit and explicit explanation function is to minimize the guilt or to avoid the focus of the problem, are used after the expression of apology strategy by ICH. In several cases, the explanation employs the word namun or however as the marker of minimizing the blame. It is quite different with NICH that only expresses explicit explanation in which it is not marked by special terms. Basically, NICH directly provides answers or explanations related to consumer complaints for this strategy. For the expression of apology, there are various sub-strategies used by NICH which consist of: expression of regret, offer of apology, and request for forgiveness, whereas ICH only applies request for forgiveness. The specific terms that employed by NICH for expressing regret is sorry, for offering apology are apologize and inconvenience, and for requesting forgiveness are please forgive and inconvenience. As in other level of hotels, ICH writes memohon maaf or to ask pardon to express request for forgiveness. Furthermore, the vocabulary used by ICH and NICH in the promise of forbearance are positive ones. Several verbs are written by ICH such as meningkatkan or to increase, menginformasikanor to inform, memperhatikan or to pay attention, memenuhi or to fulfill, menjaga or to keep, menindaklanjuti or to follow up, and dilaksanakanor to be done. Nouns are found as well includingkualitas produk(product quality), pelayanan (services), tindakan korektif (corrective action), fasilitas (facility), and pengalaman yang menyenangkan (enjoyable experience); while NICH presents verb improve in this strategy.

Another apology strategy that only appears on the ICH is minimizing the degree of offence which is almost similar to explanation since the complain receiver states the reasons for the sake of decreasing the blame; it also has no specific terms as the marker. While another apology strategy employed by NICH isthe offer of repair by utilizing sub-strategy of repair and compensation. Special vocabulary for repair is solved, but no specific vocabulary is found indicating compensation due to the various facilities that can be offered such as free stay vouchers.

\subsection{Four-star hotel}

The hotels in this classification mostly have accepted the fact that there were several complaints from their customers, and took their responsibility to send apology even though there are $13.6 \% \mathrm{NICH}$ and $23.5 \%$ ICH who did not. Similar to other classifications, expression of apology is the most popular apology strategy in $\mathrm{NICH}$ with $41 \%$, while promise of forbearance in $\mathrm{ICH}$ earns the highest percentage up to $52.9 \%$ which means that more than half of all applied strategies is dominated by this. The least favorable apology strategy for local-based hotel is expressing concern for hearer $(4.5 \%)$; whereas for international-based, expression of apology shows portion up to $23.5 \%$. The table also describes that NICH has more varied apology strategies (5 types) compared to the ICH. There are two strategies which is 
identified to be under $10 \%$ namely expressing concern for hearer and explanation; two strategies which reach between 10-20\% including offer of repair and promise of forbearance; and one strategy which gets more than $20 \%$, that is expression of apology. In ICH, the methods only consist of two types: expression of apology and promise of forbearance. In addition, both NICH and ICH have no strategy 1 and 2.

There are some cases where the managements denied taking on responsibility. The NICH, which rejects less often, is familiar with the strategy of explicit denial, justification and attack complainer, however the ICH uses implicit denial and blame complainer as well. In expressing explicit denial, NICH employs negative verb such as are not, and several strong verbs to emphasize a certain condition which is the opposite of guest's belief for instance: clarify and affirm. Different from NICH, ICH utilizes implicit denial by simply ignoring the delivered complaints. The management does not provide any answer or explanation towards the uttered complaints, it just expresses gratitude for commenting and hoping the guest will come back in the future. Both kinds of denial illustrate that the hotels does not accept the existence of complaints. Leaving out responsibility can be presented by using justification strategy. NICH explains that they have done something usual and normal; therefore, the complainer should not put the blame on them. Some adjectives are used to describe the normality of the occasion, the word equitable is found here. Besides the use of justification, there are also various examples from NICH and ICH where they actually accepts the occurred objections but they do not take the responsibility, and even blames or attacks the customers instead. The utterances are usually in the form of conditional sentence-for attacking and probability sentence-for blaming. It seems that the denial methods which utilized by NICH are harsher than ICH since NICH chose explicit denial and complainer attack.

Since the data of NICH are all in English and ICH mostly in Indonesian, the significant impact can be found in the strategy of expression of apology. English language has varieties to deliver apology, for instance by using sorry as the keyword of expressing regret, and apologize for offering apology. However, Indonesian can only employ request for forgiveness strategy because the only one way to say apology by asking forgiveness. In seeking it, the phrases memohon maaf and meminta maaf or to ask pardon must be utilized. Nevertheless, there is no difference between NICH and ICH in terms of the use of forbearance promises. Those promises show the future commitment of the hotel in maintaining the quality and lessening the assumption of other potential guests, since the interaction between the hotel and the complainer has gone to public, that the hotel is ignorance towards the complaints. From the data, the used verbs (how) which usually employed as the marker are koreksi or to correct, melakukan or to do, and to improve; while the nouns (what) consist of masukan or advice, and point berharga or valuable point. And the time marker (when) that mostly presents is phrase ke depannya or in the future. In the mixed strategies, the managements put expression of apology first, before promise of forbearance.

The strategies which only appear in NICH are explanation, offer of repair, and expressing concern for hearer. The first and second strategy do not have specific part of speech as their characteristics, so that the complain receiver directly points out (explicitly) how or why the problem occurs, and offers correction to the problem. In expressing concern for hearer, NICH gives attention to the complainer's condition after affected by the trouble. Therefore, the words that found are adjectives showing sympathy such as sad. The variations, including the option of to-be-irresponsible, here indicate that some hotels may have no strict guidelines in handling the guests' complaints; thus, the apology strategies are applied based per case or based on who is the person-in-charge in answering complaints.

\subsection{Five-star hotel}

All NICH and ICH accept that the complaints occurred and they take the responsibility. This case shows that the hotels are more aware towards their professionalism and reputation as well, so that they think it will be better to embrace the mistake, send the apology, improve the quality, and move on. The most frequently used apology strategy for NICH is expression of apology with $48 \%$, and for ICH is promise of forbearance with 43.3\%; whereas the lowest is offer of repair (4\%) for $\mathrm{NICH}$, and acknowledgement of responsibility (3.3\%) for ICH. Other strategies which employed by NICH consist of explanation and promise of forbearance in which both of them earned similar percentage up to $24 \%$. On the other hand, ICH also used explanation (6.7\%), expression of apology (30\%), and expressing concern 
for hearer $(16.7 \%)$. It can be seen that ICH in this classification present more types of strategy than $\mathrm{NICH}$.

Explicit explanation is applied by both NICH and ICH in order to state reasons why the problem occurred which are hoped to attract complainer's understanding and apology towards the problem. Based on the table, it is seen that NICH employs this strategy more than ICH which can be inferred that this kind of hotels try hard to explain rather than to promise that the problem will not happen again. ICH does different thing, no many explanations are delivered to the guests in the process of answering complaints. They mostly put on some promises to make sure that the lack of quality of services and products has been taken care of. While expression of apology is utilized frequently by either NICH or ICH, since it is like a standard step to begin the whole scenario of apology strategy; then, that strategy is followed by other strategies to enable promise of forbearance. No specific word classes are needed for explanation, but it is found that expression of apology written by NICH requires adjective sorry for expressing regret and verb apologize for offering apology. However, for $\mathrm{ICH}$, which the data are all using Indonesian language, the apology can only be expressed by using request of forgiveness due to the language structure that demands a specific verb phrase to carry the meaning of apologize such as meminta/memohon maaf or to ask/ beg pardon. In terms of diction, both NICH and ICH use verbs to explain how, by writing to improve, memperbaiki or to fix and meningkatkan or to develop/ improve; nouns that function as the object of the verbs including kualitas produk or product quality and layanan or service; and prepositional phrase that shows time namely ke depan or in the future.

$\mathrm{NICH}$ offers repair which does not done by ICH; but the case is quite rare. If the hotel does not provide repair and show its professionalism, the customers' right will be violated and cause the destruction of hotel's image. It is found that NICH has arranged compensation in order to make up the problem; and the compensation is presented by using the verb offer. On the other hand, acknowledgement of responsibility is also considered asa strategy which rarely used by $\mathrm{ICH}$; the data show the appearance of explicit acknowledgement where the management admits the failure fulfilling the customer's necessity. To show the acknowledgement, negative verb is employed such as have fallen. In addition, ICH tries to pacify the complainer for his/ her feeling or condition by putting the strategy of expressing concern for hearer. The concern was shown by the words menyesal or to feel sorry.

\section{Conclusion}

The existence of the travel reviews feature on the travel site becomes very important for the hotel management as it serves as a 'mirror' for the quality of their service. One of the internationally-based travel sites that provide this feature is Trip Advisor. Based on data analysis, there are two responses given by ICH and NICH in Indonesia in responding negative reviews on Trip Advisor namely: taking on and taking off responsibility. Taking on responsibility by ICH are found in two-star hotels by $9.1 \%$ and forstar hotels by $23.5 \%$. While in NICH, they are found in three-star hotels (19\%) and four-star hotels (13.6\%). Taking off responsibility is shown by using explicit and implicit denial, and attacking the complainer strategies. Taking on responsibility is indicated by the use of apology strategy. Based on the results, ICH uses six strategies: minimizing degree of offence, acknowledgment of responsibility, explanation, expression of apology, promise of forbearance, and expressing concern for hearer. There is a strategy that ICH does not apply in two, three, four, and five-star hotel, that is offer of repair. NICH applies five strategies, those are: explanation, expression of apology, offer of repair, promise of forbearance, and expressing concern for hearer. There are two strategies that skipped by NICH in all level of hotels, minimizing the degree of offence and acknowledgment of responsibility. The frequent strategy used by ICH is promise of forbearance, whereas by NICH is expression of apology.

\section{References}

Litvin, S., R. E. Goldsmith, \& Pan. B. 2008. Electronic word-of- mouth in hospitality and tourism management. Tourism Managementi, 29, 458-68.

Olshtain, E. \& Cohen, A.D. 1983. Apology: A speech act set. In Wolfson, N. and Judd, E (eds). Sociolinguistics and Language Acquisition. Rowley, MA: Newbury, 18-35. 
Revita, I. 2005. Daya pragmatik permintaan dalam budaya tutur masyarakat Minangkabau. Kolita 4 Atmajaya: Tingkat Internasional. Jakarta: Pusat Kajian Bahasa dan Budaya Unika Atmajaya, 7377.

Rianthong, N. Aussadavut D.\& Youji K. 2016. Improving the multidimensional sequencing of hotel rooms on an online travel agency website. Electronic Commerce Research and Applications, 17, 74-86.

Sudaryanto. 1986. Metode linguistik bagian pertama: ke arah memahami metode linguistik. Yogyakarta: Gadjah Mada University Press.

Trosborg, A. 1987. Apology strategies in native/ non-natives. Journal of Pragmatics, 11(2), 147-167. 